\begin{tabular}{|c|c|c|c|c|c|}
\hline JRL & Vol. 12 & No. 1 & Hal : 41-57 & $\begin{array}{c}\text { Jakarta, } \\
\text { Juni } 2019\end{array}$ & $\begin{array}{c}\text { p-ISSN : 2085.38616 } \\
\text { e-ISSN : 2580-0442 }\end{array}$ \\
\hline
\end{tabular}

\title{
ANALISIS KUALITAS AIR LIMBAH DOMESTIK PERKANTORAN
}

\author{
Susi Sulistia (1), Alifya Cahaya Septisya ${ }^{(2)}$ \\ Pusat Teknologi Lingkungan - BPPT dan Program Studi Analisis Kimia \\ Sekolah Vokasi, Institut Pertanian Bogor \\ Email : ${ }^{1}$ susi.sulistia@bppt.go.id dan 2)alifyacspt@gmail.com
}

\begin{abstract}
Abstrak
Air limbah domestik adalah air limbah yang berasal dari usaha dan atau kegiatan permukiman, rumah makan, perkantoran, perniagaan, apartemen dan asrama. Sebelum dibuang ke lingkungan air limbah domestik harus diolah di unit pengolahan atau Instalasi Pengolahan Air Limbah (IPAL). Sampel air diambil dari inlet dan outlet Instalasi Pengolahan Air Limbah (IPAL) yang menggunakan metode biologis (biofilter anaerob-aerob) di area perkantoran. Sampel inlet diambil dari bak ekualisasi dan sampel outlet diambil dari hasil akhir IPAL. Sebanyak 7 parameter yaitu pH, BOD/Biochemical Oxygen Demand, COD/Chemical Oxygen Demand, amonia, minyak dan lemak, total padatan tersuspensi (TSS/Total Suspended Solids) dan total coliform dianalisis setiap bulan untuk memantau hasil IPAL dan kualitas dari air limbah domestik sehingga aman jika dibuang ke lingkungan. Parameter yang digunakan didasarkan pada PERMEN LHK RI No. 68 tahun 2016 tentang kualitas air limbah domestik. Hasil penelitian menunjukkan bahwa pH (inlet 7.09 dan outlet 6.60), BOD (inlet $49.5132 \mathrm{mg} / \mathrm{L}$ dan outlet $6.1122 \mathrm{mg} / \mathrm{L}$ ), COD (inlet $287.5833 \mathrm{mg} / \mathrm{L}$ dan outlet $145.1667 \mathrm{mg} / \mathrm{L}$ ), TSS (inlet $65.8333 \mathrm{mg} / \mathrm{L}$ dan outlet $14.1667 \mathrm{mg} / \mathrm{L}$ ), amonia (inlet $158.1989 \mathrm{mg} / \mathrm{L}$ dan outlet $56.5617 \mathrm{mg} / \mathrm{L}$ ), minyak dan lemak (inlet $1822.75 \mathrm{mg} / \mathrm{L}$ dan outlet $102.25 \mathrm{mg} / \mathrm{L}$ ), dan total coliform (inlet $160000 / 100 \mathrm{~mL}$ dan outlet 300 / Nilai $100 \mathrm{~mL}$ dianalisa selama tiga bulan (Februari-April). Berdasarkan parameter tersebut, kualitas air limbah domestik area perkantoran masih dalam ambang batas untuk $\mathrm{pH}, \mathrm{BOD}$, TSS, dan total coliform, sementara COD, amonia, dan minyak \& lemak melebihi standar kualitas yang ditetapkan.
\end{abstract}

Kata kunci: air limbah domestik, instalasi pengolahan air limbah, dan parameter kualitas air limbah domestik 


\title{
ANALYSIS OF DOMESTIC WASTEWATER QUALITY IN OFFICE SPACE
}

\begin{abstract}
Domestic waste water is waste water from businesses and / or residential activities, restaurants, offices, commerce, apartments and dormitories. Before being released into the environment, domestic waste water must be processed in the processing unit or Waste Water Treatment Plant (WWTP). Water samples were collected from inlet and outlet Wastewater Treatment Plant (WWTP) using biological methods (biofilter anaerobic-aerobic) in the office. Inlet samples were took from equalization place and outlet samples were took from final output from WWTP. A total of 7 parameters (potential hydrogen, biochemical oxygen demand, chemical oxygen demand, amonia, lipid, total suspended solids, and total coliform) were analyzed every month to monitoring the result of WWTP and quality from domestic wastewater then it will be safe if thrown into the environment. The parameters used are based on PERMEN LHK RI Number 68 of 2016 about quality standards of domestic wastewater. The result show that $\mathrm{pH}$ (inlet 7.09 and outlet 6.60), BOD (inlet $49.5132 \mathrm{mg} / \mathrm{L}$ and outlet $6.1122 \mathrm{mg} / \mathrm{L}$ ), COD (inlet $287.5833 \mathrm{mg} / \mathrm{L}$ and outlet $145.1667 \mathrm{mg} / \mathrm{L}$ ), TSS (inlet $65.8333 \mathrm{mg} / \mathrm{L}$ and outlet $14.1667 \mathrm{mg} / \mathrm{L}$ ), ammonia (inlet $158.1989 \mathrm{mg} / \mathrm{L}$ and outlet $56.5617 \mathrm{mg} / \mathrm{L}$ ), lipids (inlet $1822.75 \mathrm{mg} / \mathrm{L}$ and outlet 102.25 $\mathrm{mg} / \mathrm{L}$ ), and total coliform (inlet $160000 / 100 \mathrm{~mL}$ and outlet $300 / 100 \mathrm{~mL}$ ) values were recorded for three months (February-April). Beside on these parameters, the domestic waste water quality in the office space is still within limits for $\mathrm{pH}, B O D$, TSS, and total coliform, while COD, amonia, and lipids are exceeds the set quality standard.
\end{abstract}

Keywords: domestic wastewater, wastewater treatment plant, and quality domestic wastewater parameters 


\section{PENDAHULUAN}

Dewasa ini air menjadi masalah yang perlu mendapat perhatian yang seksama dan cermat. Hal ini disebabkan untuk mendapatkan air yang bersih yang sesuai dengan standar tertentu, saat ini menjadi barang yang mahal karena air sudah banyak tercemar oleh bermacam-macam limbah dari hasil kegiatan manusia, baik limbah dari kegiatan rumah tangga, limbah dari kegiatan industri dan kegiatankegiatan lainnya. Ketergantungan manusia terhadap air pun semakin besar sejalan dengan perkembangan penduduk yang semakin meningkat (Harmayani dan Konsukharta 2007). Adanya banyak aktivitas yang dilakukan oleh manusia dapat mengakibatkan sistem pembuangan limbah rumah tangga atau yang biasa disebut sebagai limbah domestik seperti pembuangan limbah kamar mandi dan dapur sehingga limbah tersebut dapat mengakibatkan terjadinya pencemaran yang dapat mengakibatkan kerugian bagi manusia. Salah satu tempat yang akan banyak menghasilkan limbah domestik yaitu perkantoran. Banyaknya populasi manusia yang berada di perkantoran menyebabkan jumlah limbah domestik yang dihasilkan akan tinggi. Hal ini dapat menimbulkan pencemaran bagi lingkungan sekitar seperti sungai yang biasanya menjadi sumber kehidupan bagi masyarakat.

Beberapa sifat utama dari limbah domestik yang perlu diperhatikan yaitu mengandung bakteri, virus, dan parasit dalam jumlah yang banyak sehingga dapat menyebabkan penyebaran penyakit dengan cepat, kandungan detergen dalam air limbah domestik meningkatkan unsur hara terutama komponen fosfor dan nitrogen tinggi sehingga sering menyebabkan terjadinya eutrofikasi, keberadaan logam berat seperti timbal dapat meningkatkan resiko penurunan kesehatan akibat hilangnya kemampuan hemoglobin dalam mengikat zat penting seperti kalsium, timbulnya bau yang tidak sedap akibat bahan volatil, gas terlarut dan hasil samping dari pembusukan bahan organik seperti hidrogen sulfida $\left(\mathrm{H}_{2} \mathrm{~S}\right)$, serta kerugian lain apabila limbah domestik dibuang ke badan sungai yaitu berkurangnya keragaman biota air karena rutinnya senyawa B3 (Bahan Berbahaya dan Beracun) masuk ke dalam sungai (Mubin et al. 2016).

Masalah akibat limbah domestik sudah menjadi perhatian yang cukup serius sehingga dibutuhkan tenaga manusia untuk menanggulanginya. Oleh karena itu diperlukan instalasi pengolahan air limbah (IPAL) yang digunakan untuk meminimalisir pencemaran bahkan mendaur ulang limbah domestik. Jenis 
pengolahan pada IPAL terdiri dari pengolahan secara fisika, kimia, dan biologis. Keuntungan pengolahan secara biologis yaitu pengolahan yang lebih mudah dan murah dari segi operasional, dapat digunakan untuk air limbah dengan beban Biochemical Oxygen Demand (BOD) yang cukup besar dan dapat menghilangkan padatan tersuspensi (SS) dengan baik (Wijeyekoon et al. 2000).

Kualitas air limbah yang dihasilkan diharapkan memenuhi baku mutu yang telah ditetapkan oleh PERMEN LHK Nomor 68 Tahun 2016 tentang baku mutu air limbah domestik yang meliputi 7 parameter yaitu $\mathrm{pH}, \mathrm{BOD}$, Chemical Oxygen Demand (COD), Total Suspended Solids (TSS), minyak dan lemak, amonia, dan Total Coliform. Proses monitoring hasil pengolahan limbah oleh IPAL dilakukan setiap hari dan skala periodik minimal satu bulan sekali untuk mengetahui kualitas air limbah yang dihasilkan dan dilakukan evaluasi apabila terdapat kesalahan atau error.

\section{TUJUAN PENELITIAN}

Tujuan penelitian adalah mengetahui kualitas air limbah domestik di salah satu perkantoran pemerintahan di Serpong yang merupakan hasil olahan IPAL berdasarkan baku mutu yang telah ditetapkan oleh PERMEN LHK Nomor 68
Tahun 2016 tentang baku mutu air limbah domestik.

\section{TINJAUAN PUSTAKA}

Air limbah domestik adalah air limbah yang berasal dari usaha dan atau kegiatan permukiman, rumah makan (restaurant), perkantoran, perniagaan, apartemen dan asrama. Sumber air limbah domestik adalah seluruh buangan cair yang berasal dari buangan rumah tangga yang meliputi: limbah domestik cair yakni buangan kamar mandi, dapur, air bekas pencucian pakaian, dan lainya. Air limbah domestik umumnya mengadung senyawa polutan organik yang cukup tinggi, dan dapat diolah dengan proses pengolahan secara biologis (Yudo dan Setiyono 2008). Sebelum dibuang ke lingkungan air limbah domestik harus diolah di unit pengolahan atau Instalasi Pengolahan Air Limbah (IPAL)

Instalasi Pengolahan Air Limbah (IPAL) merupakan suatu sistem yang digunakan untuk mengolah limbah domestik yang dilakukan pada suatu wilayah. Biasanya digunakan di industri, perkantoran, rumah sakit, maupun wilayah rumah tangga agar limbah yang dihasilkan lebih aman pada saat dibuang ke lingkungan dan sesuai dengan baku mutu lingkungan (Karyadi 2010). Baku mutu air limbah domestik merupakan ukuran batas 
atau kadar unsur pencemar dan atau jumlah unsur pencemar yang ditenggang keberadaannya dalam air limbah domestik yang akan dibuang atau dilepas ke air permukaan. Jadi semua air limbah domestik sebelum dibuang ke perairan/ saluran umum harus diolah terlebih dahulu sampai memenuhi baku mutu yang telah ditetapkan Pemerintah. Pengolahan dapat dilakukan secara individu maupun secara terpadu. Pengolahan air limbah domestik terpadu adalah sistem pengolahan air limbah yang dilakukan secara bersama-sama (kolektif) sebelum dibuang ke air permukaan (Yudo dan Setiyono 2008).

Salah satu teknik pengolahan air limbah domestik yaitu dengan Instalasi Pengolahan Air Limbah (IPAL) biofilter anaerob-aerob yang bekerja secara biologis dengan keuntungan lebih murah, penurunan kadar pencemar yang cukup signifikan serta ramah bagi lingkungan. Analisis effluent IPAL dilakukan secara harian dan periodik yaitu minimal satu bulan satu kali untuk mengetahui kualitas air limbah domestik yang dihasilkan serta memperbaiki dengan segera apabila terdapat error pada sistem IPAL.

Parameter analisis kualitas dari limbah domestik yang digunakan mengacu kepada PERMEN LHK Nomor 68 tahun 2016 tentang baku mutu limbah domestik. Parameternya terdiri dari analisis $\mathrm{pH}$, Biochemical Oxygen Demand (BOD), Chemical Oxygen Demand (COD), Total Suspended Solids (TSS), amonia (NH3), minyak dan lemak, serta total coliform. Parameter yang digunakan ini merupakan parameter yang umumnya menjadi acuan untuk melihat kualitas limbah domestik yang telah diolah melalui IPAL yaitu baik atau tidaknya untuk dibuang ke lingkungan yang biasanya berupa sungai.

Potential Hydrogen $(\mathrm{pH})$ adalah derajat keasaman yang digunakan untuk menyatakan tingkat keasaman atau kebasaan yang dimiliki oleh suatu larutan. $\mathrm{pH}$ didefinisikan sebagai kologaritma aktivitas ion hidrogen $(\mathrm{H}+)$ yang terlarut. Koefisien aktivitas ion hidrogen tidak dapat diukur secara eksperimental, sehingga nilainya didasarkan pada perhitungan teoritis. Skala $\mathrm{pH}$ bukanlah skala absolut. $\mathrm{Hal}$ ini bersifat relatif terhadap sekumpulan larutan standar yang pHnya ditentukan berdasarkan persetujuan internasional. Nilai pH merupakan ukuran untuk konsentrasi ion hidrogen dalam larutan akuatik. Nilai $\mathrm{pH}$ menentukan sifat dari suatu larutan yaitu bersifat basa, netral atau basa. Jika $\mathrm{pH} 1$ sangat asam, $\mathrm{pH} 7$ netral, dan $\mathrm{pH} 14$ sangat basa. Nilai $\mathrm{pH}$ dapat ditentukan dengan elektrometrik atau dengan indikator warna (Zulius 2017).

Analisis COD adalah menentukan banyaknya oksigen yang diperlukan untuk 
mengoksidasi senyawa organik secara kimiawi. Chemical Oxygen Demand (COD) atau Kebutuhan Oksigen Kimia (KOK) adalah jumlah oksigen (mg O2) yang dibutuhkan untuk mengoksidasi zatzat organis dalam 1 liter sampel air, dimana pengoksidasi $\mathrm{K} 2 \mathrm{Cr} 2 \mathrm{O} 7$ digunakan sebagai sumber oksigen (oxidizing agent). Angka COD merupakan ukuran bagi pencemaran air oleh zat-zat organis yang secara alamiah dapat dioksidasikan melalui proses mikrobiologis, dan mengakibatkan berkurangnya oksigen terlarut di dalam air (Mubin 2016)

Biological Oxygen Demand (BOD) atau Kebutuhan Oksigen Biologis (KOB) adalah suatu analisa empiris yang mencoba mendekati secara global prosesproses mikrobiologis yang benar-benar terjadi dalam air. Angka BOD adalah jumlah oksigen yang dibutuhkan oleh bakteri (aerobik) untuk menguraikan (mengoksidasikan) hampir semua zat organik yang terlarut dan sebagian zat-zat organik yang tersuspensi dalam air. Parameter BOD adalah parameter yang paling banyak digunakan dalam pengujian air limbah dan air permukaan. Penentuan ini melibatkan pengukuran oksigen terlarut yang digunakan oleh mikro-organisme untuk menguraikan bahan-bahan organik (Mubin 2016).

Total Suspended Solids (TSS) merupakan material yang halus di dalam air yang mengandung lanau, bahan organik, mikroorganisme, limbah industri dan limbah rumah tangga yang dapat diketahui beratnya setelah disaring dengan kertas filter ukuran $0.042 \mathrm{~mm}$. Nilai konsentrasi TSS yang tinggi dapat menurunkan aktivitas fotosintesa dan penambahan panas di permukaan air sehingga oksigen yang dilepaskan tumbuhan air menjadi berkurang dan mengakibatkan ikan-ikan menjadi mati (Budianto dan Hariyanto 2017).

Nitrogen dalam air pada umumnya terdapat dalam bentuk organik dan oleh bakteri berubah menjadi nitrogen amonia. Amonia yang terukur di perairan berupa amonia total (NH3 dan $\mathrm{NH} 4+)$. Amonia merupakan hasil tambahan penguraian (pembusukan) protein tanaman atau hewan atau dalam kotorannya. Pupuk buatan juga menganduk amonia dan senyawanya, sehingga hasil rembesan dari pupuk yang terbawa air dapat terurai dan berkemungkinan menambah kandungan amonia dalam air (Sastrawijaya 2000).

Minyak adalah lemak yang bersifat cair. Keduanya mempunyai komponen utama karbon dan hidrogen yang mempunyai sifat tidak larut dalam air. Bahan-bahan tersebut banyak terdapat pada makanan, hewan, manusia dan bahkan ada dalam tumbuh-tumbuhan sebagai minyak nabati. Sifat lainnya 
adalah relatif stabil, tidak mudah terdekomposisi oleh bakteri (Mubin 2016)

Minyak dan lemak merupakan salah satu senyawa yang dapat menyebabkan terjadinya pencemaran di suatu perairan sehingga konsentrasinya harus dibatasi. Minyak mempunyai berat jenis lebih kecil dari air sehingga akan membentuk lapisan tipis di permukaan air. Kondisi ini dapat mengurangi konsentrasi oksigen terlarut dalam air karena fiksasi oksigen bebas menjadi terhambat. Minyak yang menutupi permukaan air juga akan menghalangi penetrasi sinar matahari ke dalam air sehingga menganggu ketidakseimbangan rantai makanan. Minyak dan lemak merupakan bahan organik bersifat tetap dan sukar diuraikan bakteri (Andreozzi et al. 2000).

Bakteri coliform merupakan bakteri indikator kehadiran bakteri patogen dan memiliki ketahanan paling besar terhadap desinfektan. Bakteri coliform yang dinyatakan sebagai nilai total coliform dapat digunakan sebagai indikator karena berbanding lurus dengan pencemaran air, semakin sedikit kandungan coliform artinya kualitas air semakin baik (Sari dan Sutrisno 2018).

\section{METODOLOGI PENELITIAN}

Sampel yang dianalisis merupakan inlet dan outlet dari Instalasi Pengolahan
Limbah (IPAL) limbah domestik di salah satu perkantoran pemerintahan di Serpong. Sampel diambil dan dianalisa setiap satu bulan sekali selama tiga bulan. Alat-alat yang digunakan yaitu $\mathrm{pH}$ meter WISSENSCHAFTLICHTECHNISCHE WERKSTATTEN (WTW) pH 315i, DO meter HORIBA model OM$71 \mathrm{G}$, botol BOD, peralatan gelas, aerator, inkubator, tabung COD, mikropipet, heating block, aduk dengan vortex, spektrofotometer UV-Vis JASCO V-530 dan kuvet, oven, neraca analitik, desikator, tabung durham, autoclave HIRAYAMA HVE-50, magnetic stirrer, hotplate, rotary evaporator HEIDOLPH, dan botol semprot.

Bahan-bahan yang digunakan yaitu buffer $\mathrm{pH} 4,7$, dan 10, kalium dihidrogen fosfat $\left(\mathrm{KH}_{2} \mathrm{PO}_{4}\right)$, dikalium hidrogen fosfat $\left(\mathrm{K}_{2} \mathrm{HPO}_{4}\right)$, dinatrium hidrogen fosfat heptahidrat $\left(\mathrm{Na}_{2} \mathrm{HPO}_{4}\right.$. $\left.7 \mathrm{H}_{2} \mathrm{O}\right)$, ammonium klorida $\left(\mathrm{NH}_{4} \mathrm{Cl}\right)$, magnesium sulfat heptahidrat $\left(\mathrm{MgSO}_{4} \cdot 7 \mathrm{H}_{2} \mathrm{O}\right)$, kalsium klorida $\left(\mathrm{CaCl}_{2}\right)$, besi klorida heksahidrat $\left(\mathrm{FeCl}_{3} .6 \mathrm{H}_{2} \mathrm{O}\right)$, standar COD CRM 50.000 ppm, asam sulfat $\left(\mathrm{H}_{2} \mathrm{SO}_{4}\right)$, perak sulfat $\left(\mathrm{Ag}_{2} \mathrm{SO}_{4}\right)$, kalium dikromat $\left(\mathrm{K}_{2} \mathrm{Cr}_{2} \mathrm{O}_{7}\right)$, kertas saring, $n$-heksana, dinatrium sulfat anhidrat $\left(\mathrm{Na}_{2} \mathrm{SO}_{4}\right.$ anhidrat), natrium salisilat $\left(\mathrm{C}_{6} \mathrm{H}_{5} \mathrm{NaO}_{3}\right)$, natrium sitrat $\left(\mathrm{C}_{6} \mathrm{H}_{5} \mathrm{~N}_{13} \mathrm{O}_{7}, \mathrm{H}_{2} \mathrm{O}\right)$, natrium nitroprusida $\left(\mathrm{Na}_{2}\left[\mathrm{Fe}(\mathrm{CN})_{5} \mathrm{NO}\right]\right.$. $\left.2 \mathrm{H}_{2} \mathrm{O}\right)$, natrium hidroksida $(\mathrm{NaOH})$, dikloro asam sianurat 
$\left(\mathrm{C}_{3} \mathrm{HCl}_{2} \mathrm{~N}_{3} \mathrm{O}_{3}\right)$, lactose monohydrate, peptone from meat, meat extract dan air akuades.

A. Pengambilan Sampel

Sampel diambil dari dua titik yang berbeda yaitu pada bagian inlet dan outlet dari Instalasi Pengolahan Limbah (IPAL) yang tersedia di perkantoran. Bagian inlet di ambil dari bak ekualisasi sedangkan bagian outlet diambil dari bagian keluaran setelah mengalami perlakuan penambahan klorin. Sampel diawetkan dengan melakukan pendinginan pada suhu $4^{\circ} \mathrm{C}$.

B. Pengukuran pH (SNI 066989.11:2004)

Prosedur pengukuran $\mathrm{pH}$ dilakukan dengan dilakukan kalibrasi terlebih dahulu pada $\mathrm{pH}$ meter dengan buffer $\mathrm{pH} 4,7$, dan 10 kemudian elektroda dibilas lalu dicelupkan ke dalam larutan sampel dan dibaca hasil pengukuran yang tertera pada layar.

C. Analisis BOD (SNI 6989.72:2009)

Larutan pengencer BOD terdiri dari 4 jenis yaitu buffer solution, $\mathrm{MgSO}_{4}, \mathrm{CaCl}_{2}$, dan $\mathrm{FeCl}_{3}$. Larutan buffer dibuat dengan ditimbang 0.854 gram $\mathrm{KH}_{2} \mathrm{PO}_{4}, 2.1756$ gram $\mathrm{K}_{2} \mathrm{HPO}_{4}, 3.3418$ gram $\mathrm{Na}_{2} \mathrm{HPO}_{4}$. $7 \mathrm{H}_{2} \mathrm{O}$, dan 0.173 gram $\mathrm{NH}_{4} \mathrm{Cl}$, kemudian dicampurkan dan ditera ke dalam labu takar $100 \mathrm{~mL}$. Larutan $\mathrm{MgSO}_{4}$ dibuat dengan ditimbang 2.25 gram $\mathrm{MgSO}_{4}$. $7 \mathrm{H}_{2} \mathrm{O}$ lalu ditera ke dalam labu takar 100
$\mathrm{mL}$. Larutan $\mathrm{CaCl}_{2}$ dibuat dengan ditimbang 2,75 gram $\mathrm{CaCl}_{2}$ lalu ditera ke dalam labu takar $100 \mathrm{~mL}$. Larutan $\mathrm{FeCl}_{3}$ dibuat dengan ditimbang 0.025 gram $\mathrm{FeCl}_{3}, 6 \mathrm{H}_{2} \mathrm{O}$ lalu ditera ke dalam labu takar $100 \mathrm{~mL}$. Setelah itu dipipet $3 \mathrm{~mL}$ dari setiap larutan dan ditera hingga $3 \mathrm{~L}$ dan di aerasi selama 12 jam.

Preparasi sampel untuk analisis BOD dilakukan dengan dipipet sampel inlet dan sampel outlet kemudian ditera di dalam botol BOD dengan larutan pengencer BOD. Blanko dibuat dengan botol BOD yang diisi seluruhnya dengan larutan pengencer. Setelah itu, larutan blanko dan sampel dituangkan ke dalam gelas piala lalu diukur nilai $\mathrm{DO}_{0}$ dengan DO meter. Setelah pengukuran selesai, sampel dan blanko diinkubasi pada suhu $25^{\circ} \mathrm{C}$ selama 5 hari. Pada hari ke- 5 dilakukan pengukuran kembali untuk memperoleh nilai $\mathrm{DO}_{5}$.

D. Analisis COD (SNI 6989-2:2009)

Pereaksi destruksi COD terdiri dari pereaksi $\mathrm{H}_{2} \mathrm{SO} 4$ dan pereaksi $\mathrm{K}_{2} \mathrm{Cr}_{2} \mathrm{O}_{7}$. Pereaksi $\mathrm{H}_{2} \mathrm{SO}_{4}$ dibuat dengan $700 \mathrm{~mL}$ $\mathrm{H}_{2} \mathrm{SO}_{4}$ pekat $(98 \%)$ ditera dengan akuades pada labu takar $1 \mathrm{~L}$ sedangan pereaksi $\mathrm{K}_{2} \mathrm{Cr}_{2} \mathrm{O}_{7}$ dibuat dengan dicampurkannya 3.0645 gram $\mathrm{K}_{2} \mathrm{Cr}_{2} \mathrm{O}_{7}$ yang sudah dikeringkan dalam oven pada suhu $103^{\circ} \mathrm{C}$ selama 2 jam dengan $200 \mathrm{~mL}$ akuades dan $50.1 \mathrm{~mL} \mathrm{H} \mathrm{SO}_{4}$ pekat (98\%) setelah itu diaduk dan ditera hingga $300 \mathrm{~mL}$. 
Kedua larutan dicampurkan dan diaduk dengan magnetic stirrer selama 24 jam.

Pembuatan kurva kalibrasi dilakukan dengan diset alat heating block pada suhu $150^{\circ} \mathrm{C}$ selama 2 jam. Larutan standar COD CRM 50.000 mg/L dipipet sebanyak $2 \mathrm{~mL}$ ke dalam labu takar 100 $\mathrm{mL}$ untuk diperoleh standar $1000 \mathrm{mg} / \mathrm{L}$. Kemudian dipipet sebanyak 2.5, 7.5, 12.5, 17.5, dan $22.5 \mathrm{~mL}$ dan ditera ke dalam labu takar $25 \mathrm{~mL}$ sehingga diperoleh konsentrasi standar 100, 300, 500, 700, dan $900 \mathrm{mg} / \mathrm{L}$. Setelah itu dipipet $1 \mathrm{~mL}$ standar ke dalam tabung COD dan ditambahkan $2 \mathrm{~mL}$ pereaksi destruksi lalu dimasukkan ke dalam heating block yang telah diset. Larutan didinginkan dan diukur dengan spektrofotometer UV-Vis pada panjang gelombang $600 \mathrm{~nm}$.

Prosedur analisis sampel dilakukan dengan dipipet $1 \mathrm{~mL}$ sampel ke dalam tabung COD lalu ditambahkan $2 \mathrm{~mL}$ pereaksi destruksi kemudian dimasukkan ke dalam heating block yang telah diset. Larutan didinginkan dan diukur dengan spektrofotometer UV-Vis pada panjang gelombang $600 \mathrm{~nm}$.

E. Analisis Total Suspended Solids (TSS) (SNI 06-6989.3:2004)

Penentuan bobot kosong kertas saring dilakukan dengan dibilasnya kertas saring dengan $20 \mathrm{~mL}$ akuades lalu dipanaskan pada oven dengan suhu $105^{\circ} \mathrm{C}$ selama 1 jam. Kertas saring didinginkan di desikator selama 30 menit lalu ditimbang. Prosedur diulangi hingga diperoleh bobot konstan. Kertas saring kosong yang telah ditimbang dipasangkan ke dalam corong lalu dibasahi dengan akuades. Sebanyak 50 $\mathrm{mL}$ sampel disaring lalu dibilas sebanyak tiga kali dengan $10 \mathrm{~mL}$ akuades. Kertas saring berisi residu dipanaskan di dalam oven dengan suhu $105^{\circ} \mathrm{C}$ selama 1 jam. Kertas saring berisi residu didinginkan di desikator selama 30 menit lalu ditimbang. Prosedur diulangi hingga diperoleh bobot konstan.

F. Analisis Amonia ( $\mathrm{NH}_{3}$ ) (IP. S-2)

Pereaksi salisilat dibuat dengan dicampurkan 6.5 gram natrium salisilat, 6.5 gram natrium sitrat, dan 0.0485 gram natrium nitroprusida lalu ditambahkan 50 $\mathrm{mL}$ akuades dan diaduk hingga homogen. Pereaksi asam sianurat dibuat dengan cara dicampurkan 1.6 gram $\mathrm{NaOH}$ dan 0.1 gram dikloro asam sianurat lalu ditambahkan $50 \mathrm{~mL}$ akuades dan diaduk hingga homogen.

Larutan baku amonia dibuat dengan ditimbang $\mathrm{NH}_{4} \mathrm{Cl}$ yang telah dikeringkan dalam oven dengan suhu $100^{\circ} \mathrm{C}$ selama 2 jam sebesar 0.191 gram lalu ditera ke dalam labu takar $50 \mathrm{~mL}$ sehingga diperoleh konsentrasi $1000 \mathrm{mg} / \mathrm{L}$ lalu dipipet $0.1 \mathrm{~mL}$ dan ditera ke dalam labu takar $100 \mathrm{~mL}$ dan diperoleh konsentrasi $1 \mathrm{mg} / \mathrm{L}$.

Deret standar amonia dibuat 
dengan dipipet larutan baku amonia 1 $\mathrm{mg} / \mathrm{L}$ sebanyak $0.40,0.80,1.60,2.40$, 3.20, dan $4.00 \mathrm{~mL}$, lalu ditambahkan sejumlah akuades hingga volume total larutan sebesar $4 \mathrm{~mL}$ sehingga diperoleh konsentrasi deret sebesar $0.1,0.2,0.4$, 0.6, 0.8, dan $1.0 \mathrm{mg} / \mathrm{L}$. Setelah itu ditambahkan $0.5 \mathrm{~mL}$ pereaksi salisilat dan $0.5 \mathrm{~mL}$ pereaksi asam sianurat lalu aduk dengan vortex hingga larutan homogen dan didiamkan selama 30 menit kemudian diukur dengan spektrofotometer pada panjang gelombang $655 \mathrm{~nm}$.

Prosedur analisis sampel yaitu 4 $\mathrm{mL}$ sampel ditambahkan $0.5 \mathrm{~mL}$ pereaksi salisilat dan $0.5 \mathrm{~mL}$ pereaksi asam sianurat lalu aduk dengan vortex hingga larutan homogen dan didiamkan selama 30 menit kemudian diukur dengan spektrofotometer pada panjang gelombang $655 \mathrm{~nm}$.

G. Analisis Minyak dan Lemak (SNI 066989.10:2004)

Sebanyak $200 \mathrm{~mL}$ sampel dimasukkan ke dalam corong pisah kemudian ditambahkan $30 \mathrm{~mL}$ n-heksana lalu dikocok kuat selama 2 menit. Larutan dibiarkan membentuk dua fase. Fase air ditampung ke dalam gelas piala dan fase organik disaring dengan $\mathrm{Na}_{2} \mathrm{SO}_{4}$ anhidrat ke dalam labu bulat kosong yang telah diketahui bobotnya. Lapisan air ditambahkan $30 \mathrm{~mL}$ n-heksana lalu dilakukan pengocongan kembali. Proses ekstraksi dilakukan 3 kali ulangan. Ekstrak digabung lalu dilakukan destilasi dengan rotary evaporator pada suhu $85^{\circ} \mathrm{C}$ hingga seluruh pelarut menguap dan tersisa residu minyak dan lemak. Labu berisi residu dipanaskan dalam oven pada suhu $102-105^{\circ} \mathrm{C}$ selama 1 jam. Setelah itu didinginkan dan ditimbang hingga diperoleh bobot konstan.

H. Total Coliform (SNI 2897:2008)

Pembuatan media agar lactose broth yaitu dengan dicampurkan 5 gram peptone from meat, 5 gram lactose monohydrate, dan 5 gram meat extract lalu dilarutkan dengan $1 \mathrm{~L}$ akuades dan diaduk hingga homogen. Sebanyak $10 \mathrm{~mL}$ media agar dimasukkan ke tabung reaksi lalu disimpan tabung durham dengan posisi terbalik dan disterilkan dengan autoclave pada suhu $121^{\circ} \mathrm{C}$ selama sekitar 150 menit. Setelah itu media didinginkan hingga suhu ruang. Setiap tabung reaksi diisi dengan $10 \mathrm{~mL}, 1 \mathrm{~mL}$, dan $0.1 \mathrm{~mL}$ sampel dengan masing-masing volume sebanyak 5 kali ulangan. Setelah itu diinkubasi pada suhu $30-35^{\circ} \mathrm{C}$ selama 24 jam lalu dihitung jumlah tabung dengan gelembung yang terperangkap pada bagian tabung durham. 


\section{HASIL DAN PEMBAHASAN}

Parameter pengujian sampel air limbah adalah berdasarkan PERMEN LHK Nomor 68 Tahun 2016 mengenai baku mutu air limbah domestik yang terdiri dari parameter kimia dan biologis seperti di tabel 1 sebagai berikut :

\begin{tabular}{lrc}
\hline Parameter & Satuan & $\begin{array}{c}\text { Kadar } \\
\text { maksimum }\end{array}$ \\
\hline $\mathrm{pH}$ & $\mathrm{mg} / \mathrm{L}$ & $6-9$ \\
$\mathrm{BOD}$ & $\mathrm{mg} / \mathrm{L}$ & 100 \\
$\mathrm{COD}$ & $\mathrm{mg} / \mathrm{L}$ & 30 \\
$\mathrm{TSS}$ & $\mathrm{mg} / \mathrm{L}$ & 5 \\
Minyak dan & $\mathrm{mg} / \mathrm{L}$ & 10 \\
lemak & jumlah/ & 3000 \\
Amoniak & $100 \mathrm{~mL}$ & \\
Total & \\
Coliform &
\end{tabular}

Persyaratan tersebut berlaku untuk rumah susun, penginapan, asrama, pelayanan kesehatan, lembaga pendidikan, perkantoran, perniagaan, pasar, rumah makan, balai pertemuan, arena rekreasi, permukiman, industri, IPAL kawasan, IPAL permukiman, IPAL perkotaan, pelabuhan, bandara, stasiun kereta api, terminal dan lembaga pemasyarakatan. Apabila salah satu dari yang diwajibkan dalam mengolah limbah tersebut tidak mematuhi aturan maka dapat dikenakan sanksi oleh pemerintah.

Hasil uji meliputi parameter kimia dan biologi yang digunakan untuk analisis kualitas air limbah domestik perkantoran yaitu pH, BOD, COD, amonia, TSS, minyak dan lemak, serta total coliform, seperti yang ditampilkan dalam tabel 2 dan 3 berikut :

\begin{tabular}{lllll}
\hline \multirow{2}{*}{ Parameter } & \multirow{2}{*}{ Satuan } & \multicolumn{3}{l}{ Air Inlet } \\
\cline { 3 - 5 } & & Februari & Maret & April \\
\hline $\mathrm{pH}$ & $\mathrm{k} .87$ & 7.36 & 7.05 \\
$\mathrm{BOD}$ & $\mathrm{mg} / \mathrm{L}$ & 44,5 & 83,1 & 20,9 \\
$\mathrm{COD}$ & $\mathrm{mg} / \mathrm{L}$ & 354 & 312 & 197 \\
TSS & $\mathrm{mg} / \mathrm{L}$ & 120 & 34 & 43.5 \\
Amonia & $\mathrm{mg} / \mathrm{L}$ & 111 & 226 & 138 \\
Minyak & $\mathrm{mg} / \mathrm{L}$ & 1652 & 3682 & 135 \\
dan Lemak & & & & \\
Total & $\mathrm{Jumlah} /$ & $16 \times 10^{4}$ & $16 \times 10^{4}$ & $16 \times 10^{4}$ \\
Coliform & $100 \mathrm{~mL}$ & & & \\
\hline
\end{tabular}

\begin{tabular}{lllll}
\hline \multirow{2}{*}{ Parameter } & \multirow{2}{*}{ Satuan } & \multicolumn{3}{c}{ Air Outlet } \\
\cline { 3 - 5 } & & Februari & Maret & April \\
\hline $\mathrm{pH}$ & & 6.92 & 6.78 & 6.11 \\
$\mathrm{BOD}$ & $\mathrm{mg} / \mathrm{L}$ & 9,63 & 3,82 & 4,88 \\
$\mathrm{COD}$ & $\mathrm{mg} / \mathrm{L}$ & 163 & 124 & 148 \\
TSS & $\mathrm{mg} / \mathrm{L}$ & 27 & 6 & 9.5 \\
Amonia & $\mathrm{mg} / \mathrm{L}$ & 58.7 & 60.5 & 50.4 \\
Minyak dan & $\mathrm{mg} / \mathrm{L}$ & \multirow{2}{*}{14} & 255 & 38 \\
Lemak & & & & \\
Total Coliform & Jumlah/ & \multirow{2}{*}{200} & 400 & 14000 \\
& $100 \mathrm{~mL}$ & & & \\
\hline
\end{tabular}

Nilai $\mathrm{pH}$ air menunjukkan tingkat keasaman atau jumlah ion hidrogen yang berada dalam suatu larutan yang akan memengaruhi kehidupan biologi didalamnya. Derajat keasaman air seharusnya netral, tidak boleh terlalu asam atau terlalu basa. Rentang $\mathrm{pH}$ baku mutu yaitu sekitar 6-9 menunjukkan $\mathrm{pH}$ netral yang akan aman apabila limbah domestik aman untuk dibuang ke 
lingkungan. Nilai pH air limbah domestik akan memengaruhi tempat dibuangnya limbah tersebut, dalam hal ini yaitu hasil pengolahan limbahnya dibuang ke sungai. Pembuangan limbah domestik akan memberi perubahan keasaman air, baik ke arah alkali maupun asam, sehingga akan sangat mengganggu kehidupan ikan dan hewan air lainnya. Selain itu, kondisi $\mathrm{pH}$ juga dapat memengaruhi tingkat toksisitas suatu senyawa kimia, proses biokimiawi perairan, dan proses metabolisme organisme air. Derajat keasaman merupakan faktor yang penting dalam proses pengolahan air untuk perbaikan kualitas air (Djoharam et al. 2018). Hasil analisis $\mathrm{pH}$ air limbah domestic dapat dilihat dari gambar 1 :

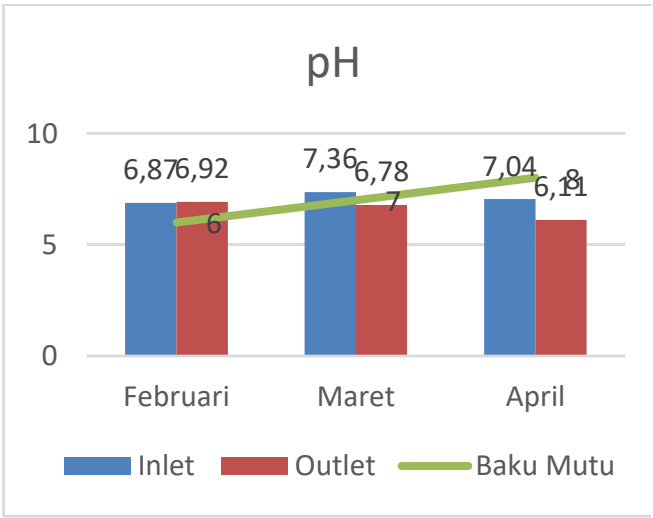

Derajat keasaman merupakan faktor yang penting dalam proses pengolahan air untuk perbaikan kualitas air. Hasil analisis $\mathrm{pH}$ terhadap air limbah domestik pada gambar 1 , menunjukkan bahwa rerata $\mathrm{pH}$ inlet (7.09) dan outlet (6.60) dalam kurun waktu selama tiga bulan masih memenuhi baku mutu yang telah ditetapkan oleh PERMEN LHK No. 68 Tahun 2016 karena masih berada pada rentang $\mathrm{pH}$ 6-8. $\mathrm{pH}$ sampel inlet yang lebih besar daripada $\mathrm{pH}$ outlet dapat terjadi karena lebih banyak terdapat zat organik terlarut. Hal ini karena pada sampel inlet belum terjadi pengolahan sehingga zat organik yang ada didalamnya belum terurai. Selain itu terdapat lebih banyak mikroba didalamnya sehingga memengaruhi proses biokimiawi perairan. $\mathrm{pH}$ outlet umumnya lebih rendah dari $\mathrm{pH}$ inlet karena pada pengolahan limbah di IPAL terdapat proses yang menghasilkan asam sehingga menurunkan nilai $\mathrm{pH}$, seperti pada proses biofilter anaerob yaitu terjadi pemecahan senyawa kompleks yang salah satunya akan menghasilkan $\mathrm{H}_{2} \mathrm{~S}$. Namun penurunan $\mathrm{pH}$ antara sampel inlet dan outlet tidak terlalu signifikan sehingga tidak memengaruhi kualitas air limbah domestik yang dihasilkan karena masih berada dalam batas aman. Hasil analisis BOD air limbah domestik dapat dilihat dari gambar 2 : 


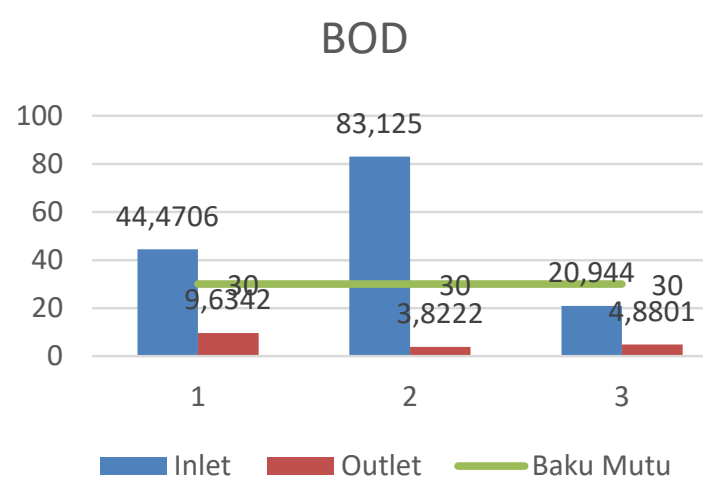

Hasil analisis BOD pada gambar 2 menunjukkan penurunan nilai rerata $B O D$ yang cukup signifikan dari inlet (49.5132 $\mathrm{mg} / \mathrm{L})$ ke outlet $(6.1122 \mathrm{mg} / \mathrm{L})$. Hal ini terjadi karena di dalam IPAL terdapat suatu media yang berbentuk bulat dengan rongga-rongga yang digunakan sebagai tempat tinggal bakteri atau mikroorganisme, sehingga membantu menurunkan konsentrasi BOD pada air limbah domestik. Dengan penurunan konsentrasi BOD mengindikasikan bahwa bahan organik yang terkandung dalam air limbah sebagian besar merupakan bahan organik yang bersifat biodegradable (dapat terdegradasi secara biologis). Gambar 3 juga menunjukkan bahwa hasil uji parameter BOD dari effluent (outlet) IPAL tersebut sesuai dengan baku mutu yang di tetapkan PERMEN LHK No. 68 Tahun 2016.

Hasil analisis COD air limbah domestik dapat dilihat dari gambar 3 :

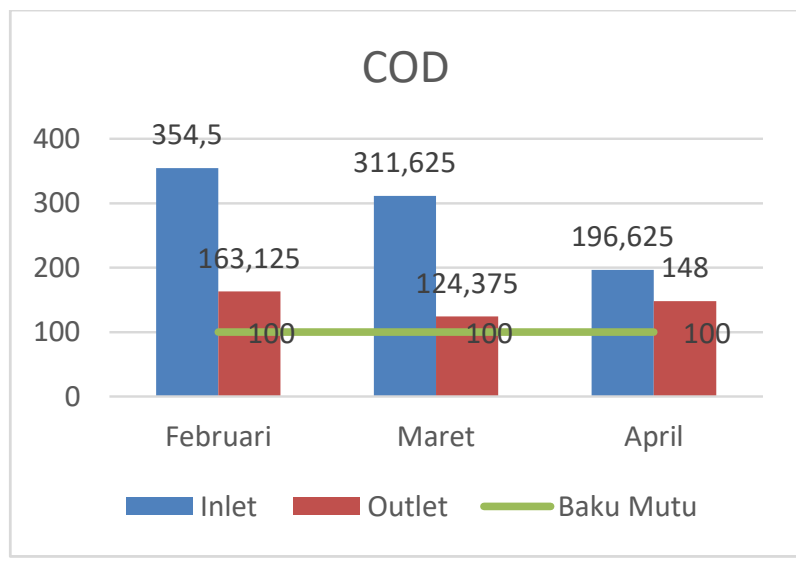

Berdasarkan hasil analisis yang ditunjukkan oleh gambar 3 diperoleh penurunan nilai rerata COD outlet (145.1667 mg/L) yang cukup signifikan yaitu sebesar $50 \%$ dari nilai COD inlet (287.5833 mg/L). Hal ini menunjukkan bahwa banyak bahan kimia maupun organik di limbah yang telah dapat dihilangkan bersama dengan padatan yang ada di dalam limbah. Salah satu proses yang berpengaruh untuk menurunkan nilai COD yaitu proses biofilter yang berarti mikroba yang berada di dalam biofilter telah aktif bekerja. Selain itu proses filtrasi juga akan menurunkan nilai COD karena proses penyaringan dan penyerapan di dalam filter-filter yang terpasang berjalan dengan baik. Meskipun begitu, nilai COD outlet masih berada di atas nilai ambang batas sehingga perlu dilakukan kajian ulang untuk mengatasi masalah tersebut. Nilai COD yang tidak memenuhi nilai ambang batas dapat terjadi karena belum sepenuhnya semua bakteri aktif dalam menguraikan bahan 
organik dalam limbah karena IPAL yang digunakan masih dalam masa optimasi sehingga terus dilakukan perbaikan. Hasil analisis TSS air limbah domestik dapat dilihat dari gambar 4 :

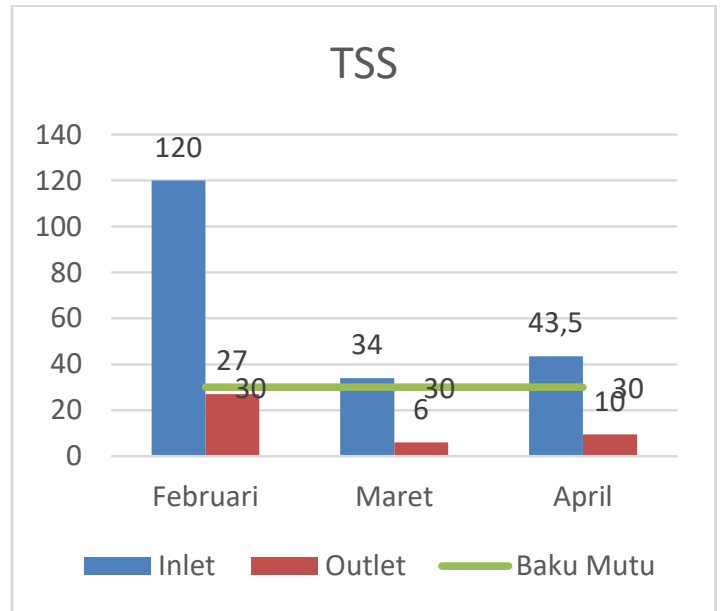

Hasil pengukuran yang dilakukan terhadap air limbah domestik (gambar 4) yang telah diproses berdasarkan parameter air limbah yaitu Total Padatan Tersuspensi (TSS) diperoleh menunjukkan bahwa rerata kadar total padatan tersuspensinya (14.1667 mg/L) masih lebih kecil apabila dibandingkan dengan kadar maksimal untuk air limbah yang telah ditetapkan oleh PERMEN LHK No.68 Tahun 2016 yaitu 30 mg/L. Nilai TSS (berupa limbah cair) tidak bersifat toksik, akan tetapi jika berlebihan, terutama TSS dapat meningkatkan nilai kekeruhan yang akan menghambat penetrasi cahaya matahari. Proses aerasi pada IPAL terjadi pemberian oksigen ke dalam limbah cair yang dapat menghancurkan endapan-endapan yang tergumpal sehingga akan mempermudah penyerapan oksigen yang menyebabkan bakteri-bakteri aerob yang berfungsi sebagai pengurai dapat bertumbuh dengan baik sehingga semakin banyak bakteri pengurai yang dapat menguraikan endapan-endapan yang tergumpal dan nilai TSS menjadi turun. Selain itu penurunan nilai TSS juga menunjukkan bahwa proses pengendapan pada IPAL berhasil sehingga nilai TSS yang diperoleh pada outlet lebih kecil dari inlet.

Hasil analisis minyak dan lemak air limbah domestik dapat dilihat dari gambar 5 :

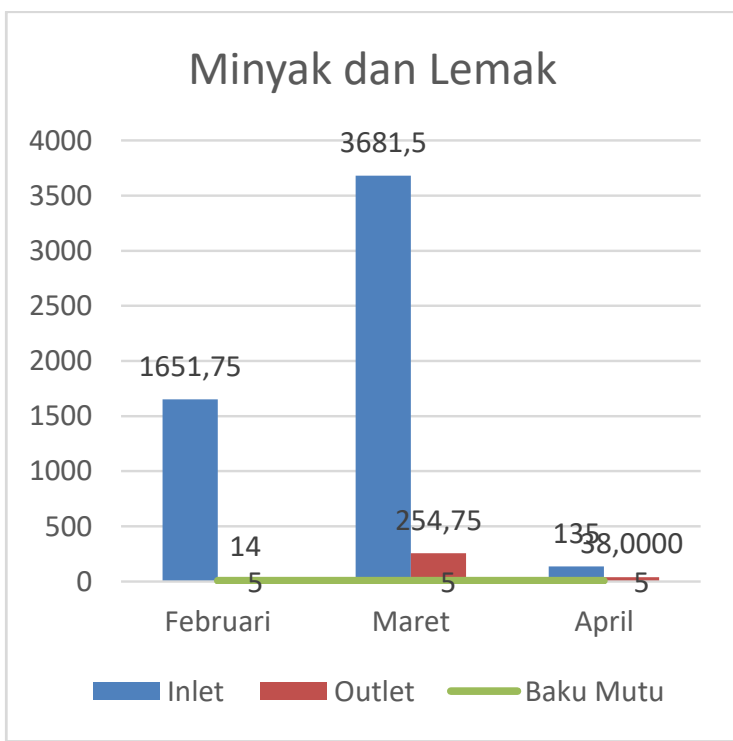

Berdasarkan hasil analisis minyak dan lemak pada gambar 8, terjadi penurunan yang sangat besar dari inlet (1822.75 $\mathrm{mg} / \mathrm{L})$ ke outlet $(102.25 \mathrm{mg} / \mathrm{L})$. Hal ini dapat terjadi karena pada saat proses pengolahan pada IPAL terdapat proses 
pemisahan minyak dan lemak yang dilakukan dengan metode gravitasi. Jika dibandingkan dengan baku mutu, kadar minyak dan lemak air limbah domestik perkantoran tersebut berada diatas nilai ambang batas. Konsentrasi yang masih tinggi dapat terjadi karena proses penghilangan lemak yang sudah menggumpal dibagian atas hanya dengan pengambilan secara manual oleh manusia sehingga dapat tersisa dan karena lemak yang sulit terdegradasi oleh bakteri maka kadarnya sulit berkurang. Konsentrasi minyak yang tinggi di dalam air limbah dapat mengganggu proses pengolahan air limbah secara kimia dan biologi berikutnya sehingga mengakibatkan biaya pengolahan menjadi mahal selain itu dapat menghambat transfer oksigen di bak aerasi yang menyebabkan kinerja IPAL menurun.

Hasil analisis amonia air limbah domestik dapat dilihat dari gambar 6 :

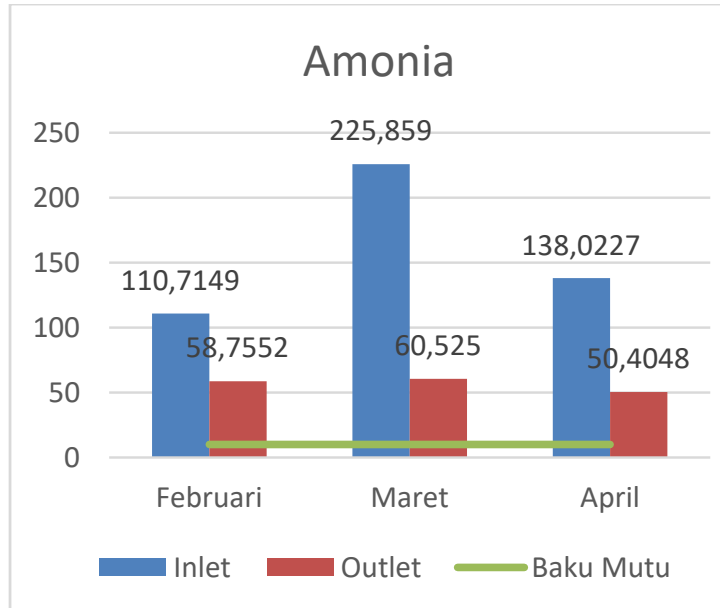

Berdasarkan hasil analisis amonia pada gambar 6 , terjadi penurunan sekitar $50 \%$ nilai amonia inlet (158.1989 mg/L) ke outlet (56. $5617 \mathrm{mg} / \mathrm{L})$. Hal ini dapat terjadi karena pada saat proses pengolahan pada IPAL, mikroba pada IPAL akan merombak amonia menjadi nitrit dan nitrat yang akan terbuang pada saat dilakukan aerasi karena menguap. Jika dibandingkan dengan baku mutu, kadar amonia air limbah domestik perkantoran tersebut berada diatas nilai ambang batas, bahkan terlampau cukup jauh. Kadar amonia yang tinggi dapat terjadi karena jumlah bahan organik yang terkandung dalam air limbah domestik tidak sebanding dengan jumlah mikroba pengurai, debit air limbah yang terlalu deras juga dapat menyebabkan kontak mikroba dengan air limbah lebih sebentar sehingga proses penguraian kurang optimum. Kadar amonia yang tinggi semakin meningkatkan jumlah konsumsi oksigen untuk menguraikan amonia menjadi nitrit dan nitrat sehingga akan menurunkan kadar oksigen terlarut dan menimbulkan bau yang tidak sedap.

Hasil analisis total coliform limbah domestik dapat dilihat dari gambar 7 : 


\section{Total Coliform}

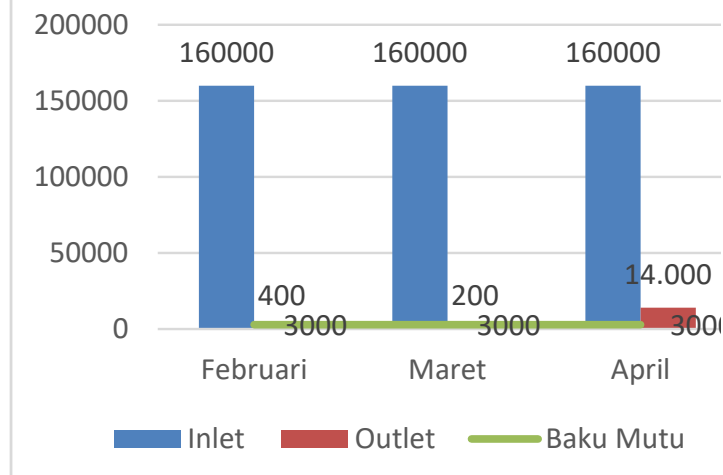

Hasil analisis air limbah domestik pada gambar dapat dilihat bahwa terjadi penurunan yang sangat besar dari inlet ke outlet sampel. Hal ini berarti pada proses pengolahan limbah dalam IPAL sudah berjalan dengan baik, salah satunya pada bak klorinasi yang berfungsi untuk mendesinfeksi air limbah sebelum dibuang. Adanya zat pembunuh klorin dan komponennya akan mematikan bakteri dengan cara merusak atau menginaktifkan enzim utama sehingga terjadi kerusakan dinding sel sehingga seharusnya dengan adanya klorinasi bakteri dalam hal ini $\mathrm{E}$. coli akan mati dan kadar MPN Coliform juga akan turun.

\section{KESIMPULAN}

Analisis kualitas air limbah domestik di salah satu perkantoran pemerintahan di Serpong dilakukan dengan 7 parameter menurut PERMEN LHK Nomor 68 Tahun 2016 yang meliputi $\mathrm{pH}, \mathrm{BOD}, \mathrm{COD}$, TSS, amonia, minyak dan lemak, serta total coliform sehingga diperoleh hasil bahwa terdapat parameter yang melebihi batas baku mutu yang ditetapkan yaitu COD, amonia, dan minyak dan lemak, sedangkan untuk $\mathrm{pH}, \mathrm{BOD}$, TSS, dan total coliform masih memenuhi baku mutu standar. Sistem IPAL air limbah domestik perkantoran harus diperbaiki untuk meningkatkan kualitas air limbah domestik yang dihasilkan sehingga lebih aman saat hendak dibuang ke lingkungan.

\section{DAFTAR PUSTAKA}

[BSN] Standar Nasional Indonesia 066989.11. 2004. Air dan air limbah: Cara uji derajat keasaman $(\mathrm{pH})$ dengan menggunakan alat $\mathrm{pH}$ meter. Jakarta (ID): Badan Standardisasi Nasional.

[BSN] Standar Nasional Indonesia 066989.10. 2004. Air dan air limbah: Cara uji kebutuhan oksigen biokimia (Biochemical Oxygen Demand/BOD). Jakarta (ID): Badan Standardisasi Nasional.

[BSN] Standar Nasional Indonesia 066989.10. 2004. Air dan air limbah: Cara uji kebutuhan oksigen kimia (Chemical Oxygen Demand/COD) dengan refluks tertutup secara spektrofotometri. Jakarta (ID): Badan Standardisasi Nasional.

[BSN] Standar Nasional Indonesia 066989.3. 2004. Air dan air limbah: Cara uji padatan tersuspensi total (Total Suspended Solid, TSS) secara gravimetri. Jakarta (ID): Badan Standardisasi Nasional.

[BSN] Standar Nasional Indonesia 2897. 2008. Metode pengujian cemaran mikroba dalam daging, telur dan susu, serta hasil olahannya. 
Jakarta (ID): Badan Standardisasi Nasional.

[BSN] Standar Nasional Indonesia 066989.10. 2004. Air dan air limbah: Bagian 10: Cara uji minyak danlemak secara gravimetri. Jakarta (ID): Badan Standardisasi Nasional.

[MENLHK] Peraturan Menteri Lingkungan Hidup dan Kehutanan Nomor 68. 2016. Baku Mutu Air Limbah Domestik. Jakarta (ID): Menteri Lingkungan Hidup dan Kehutanan.

[PTL] Instruksi Pengujian IP. S-2. 2016. Analisa N-Amonia dengan Spektrofotometri. Tangerang Selatan (ID): Pusat Teknologi Lingkungan - BPPT.

Andreozzi R, Caprio V, Insola A, Maritta R, dan Sanchirico R. 2000. Advanced oxidation processes for the treatment of mineral oilcontaminated wastewater. Water Resource. 34(2): 620-628.

Budianto S dan Hariyanto T. 2017. Analisis perubahan konsentrasi Total Suspended Solids (TSS) dampak bencana lumpur Sidoarjo menggunakan Citra Landsat Multi Temporal (Studi Kasus: Sungai Porong, Sidoarjo). Jurnal Teknik ITS. 6(1): 130-135.

Djoharama V, Rianib E, Yanic M. 2018. Analisis kualitas air dan daya tampung beban pencemaran Sungai Pesanggrahan Di Wilayah Provinsi DKI Jakarta. Jurnal Pengelolaan Sumberdaya Alam dan Lingkungan. 8(1): 127-133.

Harmayani K.D dan Konsukartha G.M. 2007. Pencemaran air tanah akibat pembuangan limbah domestik di lingkungan kumuh studi kasus Banjar Ubung Sari, Kelurahan Ubung. Jurnal Permukiman Natah. 5(2): 62 108.

Karyadi L. 2010. Partisipasi Masyarakat Dalam Program Instalasi Pengolahan Air Limbah (IPAL) Komunal Di RT 30 RW 07 Kelurahan Warungboto, Kecamatan Umbulharjo, Kota Yogyakarta. Skripsi. Yogyakarta (ID): Universitas Negeri Yogyakarta.

Mubin F, Binilang A, dan Halim F. 2016. Perencanaan sistem pengolahan air limbah domestik di Kelurahan Istiqlal Kota Manado. Jurnal Sipil Statik. 4(3): 211-223.

Sari S.F dan Sutrisno J. 2018. Penurunan total coliform pada air tanah menggunakan membran keramik. Jurnal Teknik Waktu. 16(1): 30-38.

Sastrawijaya A.T. 2000. Pencemaran Lingkungan. Jakarta (ID): Rineka Cipta.

Wijeyekoon S, Mino $T$, Satoh $H$, dan Matsuo T. 2000. Growth and novel Structural features of tubular biofilms. Journal water science and technology. 41(4-5): 129-138.

Yudo S dan Setiyono. 2008. Perencanaan instalasi pengolahan limbah domestik di rumah susun Karang Anyar Jakarta. Jurnal Teknik Lingkungan. 9(1): 31-40.

Zulius A. 2017. Rancang bangun monitoring $\mathrm{pH}$ air menggunakan Soil Moisture Sensor di SMK N 1 Tebing Tinggi Kabupaten Empat Lawang. JUSIKOM. 2(1): 37-43. 